\title{
The Effective Leadership of Vocational High Schools' Principal To Improve Teachers' Performance
}

\author{
Rusli Ismail \\ Mechanical Engineering Department \\ Universitas Negeri Makassar \\ Makassar, Indonesia \\ rusli.ismail01@gmail.com
}

\begin{abstract}
There have not been any indications showing that leadership models applied by a principal in leading education unit (SMKN Technology) affects teachers' performance. The common problem to be studied is how the implementation of models of effective school leadership on teachers' performance. This study aims to produce a product and apply effective leadership model that can improve the performance of professional teachers studied through initiation leadership structure and consideration and leadership approaches based on local wisdom. This research is expected to provide benefits as a reference model of effective leadership to improve the performance of professional teachers. This study was conducted in several phases, to make product design about leadership model and then validated. Further trial model was conducted in narrow and wide ways. Technical analysis data was conducted with quantitative analysis and qualitative and $t$ test analysis. The results reveal that the effect of leadership model with local wisdom approach is effective to improve professional teacher performance.
\end{abstract}

Keywords-leadership model, principal's, teacher performance

\section{INTRODUCTION}

Improving the quality of education is the goal of national development in the field of education and is an integral part of efforts to improve the human quality in a planned and comprehensive SA [1]. As mandated in the Act of educational system (2003) that the national education goal is "..... to bright the nation..." This means that in an effort to achieve the life of the nation is the responsibility of the education, especially in preparing students to be subject devoted to the Almighty God, noble, tough, creative, independent, democratic and professional in their respective fields.

School as an important vehicle in the formation of qualified human resources will be realized through education unit level. The purpose of management is to increase and improve the capacity inherent in human capabilities and skills to contribute [2].

The situation shows that in the implementation of the school-based management it is necessary that the principal is able to perform the function of leadership, to align leadership, follower and situation. Therefore, a principal is one of the factors that can encourage schools to realize the vision, mission, goals and objectives of the school through planned programs.

In South of Sulawesi there are main cultural values specially on leadership such as getteng, allempureng, taro ada taro gau, and usual behavioral leadership like sipakatau, sipakalebbi and sipakainga' and tudang sipulung implemented in meeting models.

\section{A. Why Principal}

In achieving a good quality of education, a school success is determined by the role of school leadership. Leader in the field of education will effectively act as steady as educators[3]. This is because the role of the principal is very strong in influencing the behavior of human resources, in this case teachers and other supported resources.

In terms of leadership, effective principals in the schoolbased management must meet the criteria as proposed by Wahyosumidjo (2010) as follows: (1) Able to empower teachers to implement good and productive learning process, (2) Able to implement duties and tasks in accordance with the set time, (3) Able to establish a harmonious relationship with the school community and the community around the school, so as to involve them actively in order to realize the goal of school and education, (4) Successfully apply the principles of leadership corresponding to the maturity level of teachers and other school employees, (5) Able to work with the management team, (6) Successfully realize a productive school purposes in accordance with the conditions set.

Furthermore Wahjosumidjo (2010) stated that the low quality of education units in the country and Indonesia at the present time is one of the effects of this form of school leadership organization that manages the educational unit, because leadership is a key factor for effective school or work, and if the head understands the various forms of school leadership as the need occurs.

Observations indicate that the pattern has not indicated any major school leadership in vocational technology in the city of Makassar which is effective in improving teacher performance. Besides, there is not a hint in the implementation of school leadership that can be used as a model that can improve the performance implications of professional teachers. 
In addition to aspects of school leadership, things that need to be taken into consideration is how the performance of teachers, especially teachers' professional performance to the quality of education. The spotlight is more on the inability of teachers in the implementation of the learning process, so it comes down to the decline in the quality of education. Expectations created new synergies in future schooling and environmental concern which is the establishment of an effective and efficient performance in any existing structures on schooling.

\section{B. Data of Vocational School In South Sulawesi, Indonesia}

According to the data from Department of Education of South Sulawesi province, in 2010/2011, of the 30 (thirty) schools having a course of mechanical engineering expertise, there were 7 (seven) schools which was located in the city of Makassar, consisting of 3 (three) SMK and 4 (four) private vocational schools.

Data showed that South Sulawesi province declined 7.2 percent in the National Examination in 2010. Graduation rate in South Sulawesi in 2010 was only 86.60 per cent whereas in the year 2009 it reached 93.80 percent. Regarding the rate of Vocational School (SMK), South Sulawesi was in the rank 17th. While the graduation rate of vocational school Makassar plummeted.

Of the total 1,623 UN participants, only 845 (52.06 percent) passed. The remaining 778 (48.04 per cent) did not pass the exam. (http://tribunnews.com). The data in Makassar City Department of Education Academic Year $2010 / 2011$ showed that the level of vocational, reaching $99.09 \%$ passing rate students who do not pass is 69 students of the $7593 \mathrm{UN}$ participants. (http://www.seputarindonesia.com/edisicetak/content/view/399040/).

Based on the observation data in the field, some school principals do not come from the relevant educational background with the vocational school (i.e. technology) so that it can lead to the assumption that leadership in vocational profile is not relevant to the principal's leadership competencies. Beside,most professional teachers are men so it can be assumed that the relationship is disharmony. A pattern of relationships run on their own so it is not integrated in a pattern of leadership that can develop a good performance on the principal and the teachers.

The description is supported by the facts on the field that the number of students of vocational schools in South Sulawesi who succeed in achieving learning outcomes is low. Therefore, a research should be carried out regarding school leadership as a model of effective leadership to improve the performance of professional teachers, and ultimately improve student achievement. Moreover, the problems are how a model of leadership of principal with touching of local wisdom can enhance the performance of professional teachers. The data shows that principal's leadership and teachers' performance at vocational schools in south Sulawesi, Indonesia is not good.

The common purpose of this research was to generate and apply a product model of effective leadership to principal of state vocational school which can improve the performance of professional teachers assessed through structure initiation and consideration leadership structure with touching local wisdom approach.
The specific purpose is doing the design for content of an effective leadership model of principal in state vocational and Technology school in view of the initiating structural approach and consideration and local wisdom in cultural approaches.

Approach to the study of leadership islearned through a variety of different ways according to the conception of leadership and research methodology. So the study of leadership treats at a subordinate or influence aspects such as the behavior of each other targeted studies without hooking each other which actually is a series of problems in the field of leadership.

Leadership research can be grouped into 4 (four) kinds of approaches: a Power influence approach, Trait approach, Behavior approach, and Situational approach.

James M. Liphans et. al (in Wahjosumidjo, 2010) states that the historical approach to the analysis of models of leadership are: (a) Psychological approach, (b) Situational approach (c) Behavior approach, (d) Contingency approach.

Henry Mintzberg concluded that all leaders have the formal authority of the organizational units they lead. As a result of the formal authority, a leader has the status or position. Because of his position, then the leader is involved in cooperative relationships with subordinates, co-leader with the necessary information in decision making.

Koontz describes the function of leadership is to induce or persuade all subordinates of followers to contribute willingly to organizational goals in accordance with the maximum capacity.

The leadership description of leader behavior is defined into two dimensions: initiating structure and consideration. Initiating structure refers to "a leader's behavior in delineating the relationship between himself and members of the work group and in endeavoring to establish well-define patterns of organization, channels of communication, and methods of procedure". Meanwhile, consideration refers to "behavior indicative of friendship, mutual trust, respect, and warmth in the relationship between the leader and the members of his staff."

Bugis culture is known for some leadership qualities that serve as guidelines in leading a social life like : Sipakatau ', is human nature to look human like humans, Sipakainge ', is nature to reminiscent other people, Sipakalebbi, which forbids us to see the nature of human beings with all its shortcomings [4].

\section{Principal Leadership Models}

In order to perform the role and function as managers, principals should have the right strategy to empower education personnel through collaboration or cooperation, providing opportunities for education personnel to improve the profession in encouraging the involvement of all educational personnel in a variety of activities that support school programs. As an educator, the principal must have the right strategy to improve the professionalism of educational personnel in the school, creating a school climate that is conducive [5].

Wahjosumidjo (2010:108), states that an integral part of the principal's leadership is clearly related to: (1) The school principal is a leadership position that is both complex and 
unique. The success of the school principal as a leader will be determined by the factors underlying its leadership. (2) School leadership positions are complex and unique that demands certain requirements as well as requirements of leadership in general, also require special requirement that is the principal competence. (3) General and specific qualification requirements generate the principal profiles, the principal is the ideal figure qualified in accordance with the specifications of the desired principal office.

\section{Professional Teacher Performance}

"Performance is an activity of a person in performing basic tasks assigned to him" [6]. Performance and responsibilities are expressions of all the potential and ability of a person and demanded a full and complete ownership. Thus the appearance of a person's performance is a result of the existence of a job or task performed in accordance with the profession and the individual job description.

Teacher performance is critical to the performance of teachers that are very important to be noticed and evaluated for teacher professional task. Teachers have a responsibility that can be broadly grouped as follows: (1)Teachers as teacher, (2)Teachers as mentors and (3)Teachers as class administrator [7]

From the above statement, it can be said that teacher performance indicators include, among others: Ability to plan and prepare teaching, Mastery of the material to be taught to students, Mastery of strategic methods, Assignments to students, Ability to manage classroom And ability to assess and evaluate [8].

\section{E. Hypothetic}

Leadership model with initiation structure and consideration approach with local wisdom can have positive and significant effect on the performance of teacher professional. This study is expected to produce an outcome that is effective leadership model for the principal's of vocational technology school in an effort to improve the performance of professional teachers in Makassar through the study of leadership initiation structural and considerations and based local wisdom.

\section{METHOD}

Implementation phases of the research were conducted the following steps:

- Perform search, assessment literature that discuss models of leadership.

- Observations and field surveys to observe the situation carefully and systematically on principal leadership in the institution he leads, i.e. Vocational and Technology school majoring in mechanical engineering.

- Perform design or product design leadership models which are then validated by construct validity as well as content validity through expert / experts who are competent and then tested at the school taken as samples.

- Tested narrowly on one school to get a picture of the field to empirically evaluate the effective model that can improve the performance of professional teachers.
- Conduct research to test the wider applicability in another SMKN Technology.

Subjects in this research were 2 principals and 66 professional teachers in the experimental method to get data about the implications of the implementation of effective models of leadership in improving the performance.

Processing and data analysis were done with descriptive analysis. The analysis was conducted to describe the mean (average) and deviation standard to describe the pattern of leadership principal of State vocational and Technology school in Makassar. Inferential statistical analysis t test was done to see the influence model of effective leadership principal of vocational Technology school in improving the performance of professional teachers. From the analysis of data, the leadership profile of Principal of State Vocational and Technology school described as hypothetical model of leadership is improving the performance of professional teachers. Further descriptive analysis was done to describe model of effective leadership of principal of State Vocational Technology school as the implementation of the improved performance of professional teachers.

\section{RESULT AND DISCUSSION}

\section{A. Results of Statistical Analysis}

Teachers Performance After Extensive Trials leadership model at 2 Vocational high schools ( SMTI and SMKN 2 Makassar ).

TABLE I. Statistic of Teacher Performance in SMTI After $2^{\text {ND }}$ TRIALS

\begin{tabular}{|l|l|l|}
\hline \multirow{2}{*}{ N } & \multicolumn{1}{|c|}{ Valid } & \multicolumn{1}{c|}{ 32 } \\
\cline { 2 - 3 } Mean & \multicolumn{1}{c|}{ Missing } & \multicolumn{1}{c|}{$\mathbf{0}$} \\
\hline Std. Error of Mean & 83.3438 \\
\hline Median & .97923 \\
\hline Mode & 81.0000 \\
\hline Std. Deviation & 81.00 \\
\hline Variance & 5.53936 \\
\hline Range & 30.684 \\
\hline Minimum & 29.00 \\
\hline Maximum & 79.00 \\
\hline Sum & 108.00 \\
\hline
\end{tabular}

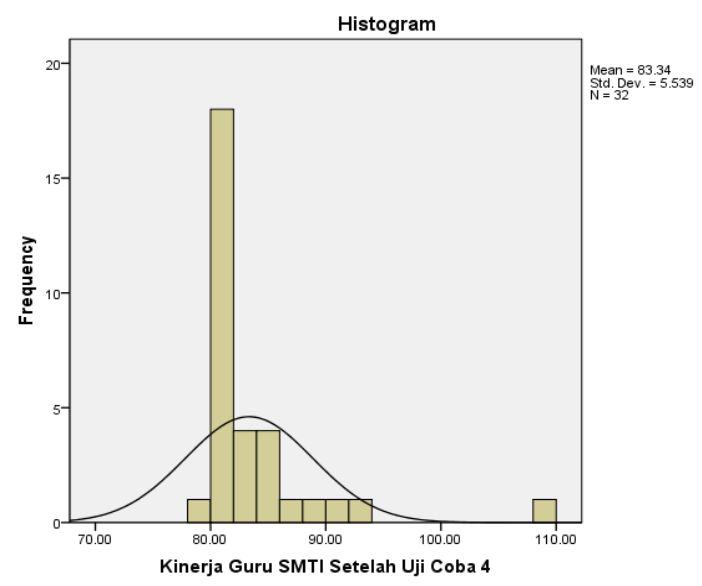

Fig. 1. Graph Diagram of Professional Teacher Performance at SMTI Makassar after $2^{\text {nd }}$ trial 


$\begin{array}{ll}\text { The highest score } & : 4 \times 27=108 \\ \text { Lowest score } & : 1 \times 27=27 \\ \text { Range } & : 81 \\ \text { Class interval } & : 81: 4=20.25=20\end{array}$

TABLE II. DESCRIPTION OF Professional TEACHER PERFormance AT SMTI MAKASSAR

\begin{tabular}{|l|l|l|l|l|}
\hline No & \multicolumn{1}{|c|}{ Interval } & \multicolumn{1}{|c|}{ Criteria } & Frequency & Percentage \\
\hline 1 & $27-47$ & Worst & 0 & $0 \%$ \\
\hline 2 & $48-68$ & Bad & 0 & $0 \%$ \\
\hline 3 & $69-89$ & Good & 29 & $90,62 \%$ \\
\hline 4 & $90-110$ & Better & 3 & $9,38 \%$ \\
\hline
\end{tabular}

Professional teacher performance in SMTI Makassar after the principal effective leadership model is applied (after 2nd trials) is considered to be in good category. Thus an increase in the performance of professional teachers were widely tested (1st trial to 2 nd trials).

TABle III. Statistic of Teacher Performance in SMKN 2 After $2^{\text {ND }}$ TRIAL

\begin{tabular}{|l|l|l|}
\hline \multicolumn{1}{|c|}{$\mathbf{N}$} & \multicolumn{1}{c|}{ Valid } & \multicolumn{1}{c|}{$\mathbf{3 4}$} \\
\cline { 2 - 3 } & \multicolumn{1}{c|}{ Missing } & \multicolumn{1}{c|}{$\mathbf{0}$} \\
\hline Mean & 89.6765 \\
\hline Std. Error of Mean & 1.35678 \\
\hline Median & 88.0000 \\
\hline Mode & 85.00 \\
\hline Std. Deviation & 7.91133 \\
\hline Variance & 62.589 \\
\hline Range & 28.00 \\
\hline Minimum & 77.00 \\
\hline Maximum & 105.00 \\
\hline Sum & 3049.00 \\
\hline
\end{tabular}

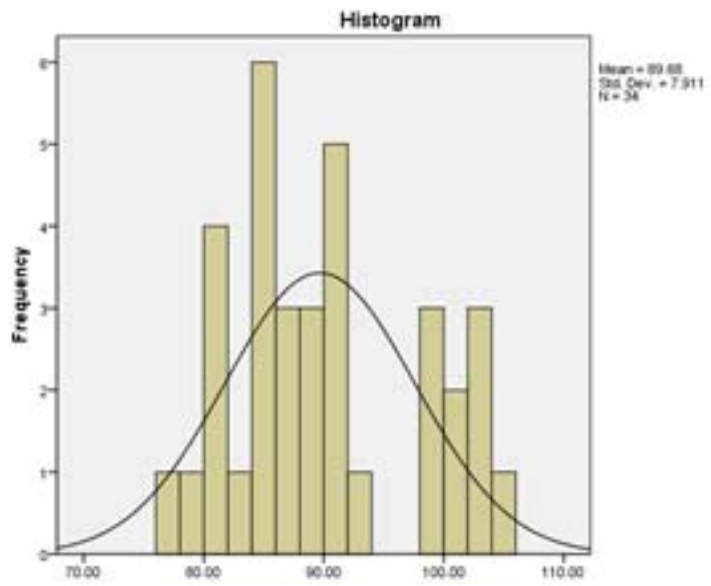

Fig. 2. Graph Diagram of Professional Teacher Performance at SMKN 2 Makassar after $2^{\text {nd }}$ trial

$$
\begin{aligned}
& \text { The highest score }: 4 \times 27=108 \\
& \begin{array}{ll}
\text { Lowest score } & : 1 \times 27=27 \\
\text { Range } & : 81 \\
\text { Class interval } & : 81: 4=20.25=20
\end{array}
\end{aligned}
$$

TABLE IV. DESCRIPTION OF Professional TEACHER PERFormance AT SMKN 2 MAKASSAR

\begin{tabular}{|l|l|l|l|l|}
\hline No & \multicolumn{1}{|c|}{ Interval } & Criteria & Frequency & Percentage \\
\hline 1 & $27-47$ & Worst & 0 & $0 \%$ \\
\hline 2 & $48-68$ & Bad & 0 & $0 \%$ \\
\hline 3 & $69-89$ & Good & 19 & $55,88 \%$ \\
\hline 4 & $90-110$ & Better & 15 & $44,12 \%$ \\
\hline
\end{tabular}

Thus professional performance at SMKN 2 Makassar after the model of effective leadership principals is applied (after 2nd trial) is considered to be in good category. Thus an increase in the performance of professional teacher-tested from 1 st to 2 nd was wide trial.

\section{B. Test analysis at 2 Vocational High Schools}

\section{1) Test analysis results at SMKN 2 Makassar}

Based on data analysis in table 2, the trials was larger in SMKN 2 Makassar that the average value of 2 test larger and significantly different from 1 value trials (89 676> 79 441). To make a decision, whether the difference was significant or not, the price of the $t$ need to be compared with the price chart with $\mathrm{n}-2 \mathrm{df}=32$. Based on the $\mathrm{t}$ distribution table, if $\mathrm{dk}$ 32 , to test one side with an error level of $5 \%$, then the price of t table 1.695. Based on these calculations it turns out that $t$ is greater than $t$ table $(13.041>1,695)$. The conclusion is that the hypothesized model was proved to be effective.

2) Test analysis results at SMTI Makasar

Based on the analysis of data in the SMK-SMTI Makassar table 4:38, the average value of 2 larger trials and significantly different from the value of test 1 (83.344>71.719). To make a decision, whether the difference was significant or not, the price of the t need to be compared with the price chart with $\mathrm{dk} n-2=30$. Based on the $\mathrm{t}$ distribution table, if $\mathrm{dk} 30$, to test one side with an error level of $5 \%$, then the price $t$ table of 1,697. Based on these calculations it turns out that $\mathrm{t}$ is greater than $\mathrm{t}$ table $(15.9059>1.695)$. The conclusion is that the hypothesized model was proved effective.

From the t test results in 2 vocational schools technology, it seems clear that the application of the approach to principals leadership model of structure initiation, consideration and a touch of local culture wisdom suggests each has a significant impact on performance improvement of professional teachers. This is illustrated by the results of the $t$ test analysis models that describe more extensive testing after the model is applied to SMK-SMTI Makassar. This showed significantly better effect that the value of $t$ is greater than $t$ table (15.9059> 1.695), The mean value or average price achieved continues to show improvement towards excellent after the model is applied, it is described on the average value of the SMK -SMTI reached 83.344 or $9.38 \%$ and can reach 89.676 in SMKN 2, or 44, 12\%. Therefore, based on data analysis of research variables, and test is limited to the application of the model and test a wider, it can also be concluded that the effectiveness of school leadership models (SMK) technology structure approach initiation, consideration and wisdom shown is proven to improve the performance of professional teachers.

\section{Results of Implementation Leadership Model}

Results of feasibility model of principal leadership assessment form is done through observation based on the initiation steps of leadership, leadership consideration, step approach to local wisdom, and the principal attention to the performance of professional teachers. In the limited testing before deploying the model, it shows that the structure of the initiation step of leadership, leadership consideration, approach local knowledge and professional teacher performance improvements can be achieved only an average of two of the five dimensions or $40 \%$ and after the implementation of the model can be implemented across 
dimensions of $100 \%$, more details can be seen as illustrated in the following table.

TABLE V. IMPLEMENTATION LEADERSHIP MODEL OF INITIATION STRUCTURE, CONSIDERATION, AND LOCAL WISDOM APPROACH TO TEACHERS PERFORMANCE IMPROVEMENT AT SMTI MAKASSAR

\begin{tabular}{|c|c|c|}
\hline $\begin{array}{c}\text { Before the model } \\
\text { is applied }\end{array}$ & Dimension & $\begin{array}{c}\text { Once the } \\
\text { model is } \\
\text { applied }\end{array}$ \\
\hline $40 \%$ & Leadership structure of the initiation & $100 \%$ \\
\hline $40 \%$ & consideration leadership & $80 \%$ \\
\hline $40 \%$ & local wisdom Approach & $100 \%$ \\
\hline $20 \%$ & Improved teacher performance & $100 \%$ \\
\hline
\end{tabular}

The data indicate that the feasibility of effective leadership in SMTI Makassar leadership structure for variable five-step initiation of the leadership that has been accomplished previously, shows only two that concern the exercise direction and coordination of professional duties of teachers, as well as concerns about the implementation of applying standard pattern learning device.

Another dimension in the research variable that has not been implemented include the feasibility of leadership in terms of the creation of patterns of cooperation and establish communication. The principal has not implemented appreciation of teacher performance measures in the form of awards and school leadership regarding the assessment of the work of professional teachers in the achievement of learning outcomes.

Consideration of leadership that carried only the principal dimensions provide the opportunity for teachers to develop competence, and appreciated the success achieved by the teacher. while the measures are not yet done are 1) create an atmosphere of intimacy in establishing communication in meetings and 2) give attention to the problems faced by teachers to increase their competence. In the observation, the data implementation indicate that school leadership approaches apply local knowledge in the application, limited to the value of discipline aspect getteng in attendance, and the application of the provision suggestions in solving the problems associated with sipakainga the cultural values of local wisdom.

The effect of the implementation of the principal's leadership is reflected in the achievement of the performance of teachers who only shows the principal attention on meeting the learning and mastery learning targets. While concern about the quality of lesson preparation, teaching practices and learning development work as well as the concern of teachers' organizational activity.

Separately enforceability of the model is also tested on SMKN 2 Makassar in order to see the results of testing a wider implementation of effective principal leadership models in improving the performance of the professional teacher. Feasibility of observational data indicates that the dimensional model of the structure of leadership initiatives, leadership considerations with local wisdom approach, and the dimensions of teacher performance improvement can be seen in the table 6 .

Observation data in the model feasibility Makassar SMKN 2 illustrates that the average dimension of the variables on the principal's leadership and performance variables are at $40 \%$. This shows that each dimension of the variables before the model is enforced only an average of two out of five was executed.

TABLE VI. IMPLEMENTATION LEADERSHIP MODEL OF INITIATION STRUCTURE, CONSIDERATION, AND LOCAL WISDOM APPROACH TO TEACHERS PERFORMANCE IMPROVEMENT AT SMKN 2 MAKASSAR

\begin{tabular}{|c|c|c|}
\hline $\begin{array}{c}\text { Before the model } \\
\text { is applied }\end{array}$ & Dimension & $\begin{array}{c}\text { After the } \\
\text { model is } \\
\text { applied }\end{array}$ \\
\hline $40 \%$ & Leadership structure of the & $100 \%$ \\
\hline $40 \%$ & considiation & $100 \%$ \\
\hline $40 \%$ & local wisdom Approach & $100 \%$ \\
\hline $40 \%$ & Improved teacher performance & $100 \%$ \\
\hline
\end{tabular}

Structural dimensions of leadership initiatives implemented the direct coordination of the principal professional duties of teachers, and assess the work of teachers in student achievement. As for the creation of patterns of cooperation and establish communication, the principal implement appreciations to teachers' achievements in the form of awards, and the application of the standard pattern has not been seen in observational learning enforceability of school leadership.

Similarly, the leadership dimension considerations show only two of the five dimensions materialize or $40 \%$, which gives principals and teachers' competence development opportunities to give an appreciation of the success of teacher performance.

Three other dimensions such as the creation of intimacy and communication in the meeting as well as giving attention to the problems faced by teachers have not appeared in a feasibility model of school leadership. Furthermore, the approach described local wisdom in leadership effectively implemented only in the affirmation of discipline (getteng values). Provision of advice and problem solving for professional teachers is (sipakainga) values. Meanwhile values of sipakalebbi are manifested in communication. Moreover, values of sipakatau are in recognition of the achievement of the performance of professional teachers. Besides, application patterns of Tudang Sipulung in school meetings needs to be improved.

A description of the professional of teachers' performance in SMK 2 shows only two dimensions in implementation of the school leadership, that is the principal attention on the quality of learning and attention in preparation for the fulfillment of the target learning and mastery learning. Whereas the other dimensions were not, such as principals give attention to the quality of learning, professional development work, and the activity of teachers in the organization interact.

Based on data analysis from observational feasibility model of effective leadership principals at 2 SMK, it shows an improvement in performance of technology professional teachers. After the model was implemented on the enforceability of any dimension previously only an average of $40 \%$ to $100 \%$, thus it can be concluded that in terms of practicality, a model of effective leadership principals to improve the performance of professional teachers is met. Thus from descriptive analysis and inferential statistical descriptive analysis, a feasibility model of the effectiveness and practicality element models can be fulfilled. 


\section{CONCLUSION}

According to research result that preliminary investigation on field observation shows that principal's leadership to improve performance of professional teacher at state vocational and technology schools before model was implementation is bad, then, after the leadership model was implemented the performance of professional teacher was good. So the conclusion is the effective leadership model of initiating structural and consideration, and local wisdom approach for Principal's of state vocational and technology high schools can improve the performance of professional teachers In Makassar, South Sulawesi, Indonesia.

\section{REFERENCE}

[1] Ahmadi. Abu and Uhbiyati. Nur, Ilmu pendidikan, Jakarta : PT. Rineka Cipta, 2001.

[2] Sedarmayanti, Manajemen Sumber Daya Manusia, Reformasi Birokrasi dan Manajemen Pegawai Negeri Sipil. Bandung : RefikaAditama, 2007.

[3] Sondang P. Siagian, 2003. Teori dan Praktek Kepemimpinan, Jakarta : Rineka Cipta

[4] Taufiq. Muhammad, http://bolongpute.blogspot.com/2011/08/sipaka tau-sipakainge-sipakalebbi.html, 2011.

[5] E. Mulyasa, Kurikulum Tingkat Satuan Pendidikan, Bandung : Remaja Rosdakarya, 2006.

[6] Kusnan.,Kemampuan Manajerial Kepala Madrasah dan Impikasinya Terhadap Kinerja Guru, Jurnal IQRA Volume 3, Januari-Juni 2007.

[7] Danim. S, Inovasi Pendidikan. Bandung : CV. Pustaka Setia, 2001.

[8] Saondi, Ondi, Suherman. A, Etika Profesi Keguruan. Bandung : PT. Refika Aditama, 2010 